\title{
Titrálásos módszer talajok redox pufferkapacitásának meghatározására
}

\author{
IBRAHIM ISSA, RÉTHÁTI GABRIELLA, CZANIK PÉTER és \\ CZINKOTA IMRE
}

Szent István Egyetem, Talajtani és Agrokémiai Tanszék, Gödöllő

\section{Bevezetés, irodalmi áttekintés}

A talajok levegőzöttségének függvényében nagymértékben változik a redoxpotenciál, amely közvetlenül befolyásolja sok növényi tápelem felvehetöségét, de közvetve gyakorlatilag a talaj összes lényeges tulajdonságát. A talaj redoxpotenciáljának mérésével sok probléma van, mivel gyakorlatilag csak helyszíni vizsgálatot fogadhatunk el jellemző módszernek. Azonban ezzel is gondok vannak, mivel a redoxpotenciál értékek a talaj pillanatnyi víztartalmától, levegőzöttségétől, de még a napszaktól és hőmérséklettől is jelentősen függenek. A laboratóriumba szállított talajminták levegőzöttsége általában eltér a helyszínen jellemző viszonyoktól, így a minta redoxpotenciálja jelentősen változhat, nem is beszélve a szárított talajmintákról, melyek gyakorlatilag alkalmatlanok a redoxpotenciál meghatározására.

A talajok redoxpotenciáljának mérése a szakirodalomban vitatott téma jelenleg. Alapvetően két elfogadott módszer létezik: az első módszer szerint megmérjük a talajok redox aktív alkotórészeinek koncentrációját (pl. oldott oxigén, nitrát, szulfát, vasII, vasIII, mangánII, mangán IV, szulfid, metán) és a mért koncentrációértékekből becsülhetjük a talaj redox állapotát. Ennek a módszernek a hátránya, hogy igen körültekintő mintavételezést igényel és sok, viszonylag költséges vizsgálatot kell elvégeznünk. A másik módszer szerint inert elektróddal (platina, vagy arany) egy galvánelemet összeállítva megmérjük az elektromotoros erőt, amelyből a redoxpotenciál közvetlenül számítható. A módszer hátránya, hogy az elektród érintkezése a talajszemcsékkel erősen befolyásolja az eredményt, továbbá nagyon rossz az ismételhetősége, emiatt ez a módszer szintén erősen vitatott a szakirodalomban (VEPRASKAS, 2002).

A felszín alatti geológiai rendszerek nemcsak a redoxpotenciáljukban különböznek egymástól, de talán még fontosabb a pufferképességük, mellyel állandósítják a redox állapotokat a külső változtató hatásokkal szemben. A rendszer, mely képes stabilizálni az Eh értékét nagy redoxkapacitással rendelkezik, teljesen analóg módon a pH pufferkapacitással, amely csökkenti a sav-bázis állapotban bekövetkezö változásokat. A redoxkapacitás a $\mathrm{pH}$ pufferkapacitással analóg módon definiálható. A redoxkapacitás fogalma segít megérteni sok nagyon fontos folyamatot a talajban

Postai cím: I. ISSA, Szent István Egyetem, Mezőgazdaság- és Környezettudományi Kar, Talajtani és Agrokémiai Tanszék, 2103 Gödöllö, Páter K. u. 1.E-mail: ibrissaa@yahoo.com 
és a talajvízben (VAN BREEMEN \& WIELEMAKER, 1974) és üledékekben (HUTCHEON et al., 1993).

AMONETTE és munkatársai (1999) szerint nagy nehézségekbe ütközik a különböző vasvegyületek elemzése a talajban, mivel az analitikában használt kivonószerek jelentősen eltérő mértékben távolítják el a felületről a különböző oxidáltsági fokú formákat. Ezzel gyakorlatilag teljesen eltérő koncentrációviszonyokat mérhetünk a kivonatban, mint eredetileg a szilárd fázison.

A nehézfémek koncentrációja, kémiai viselkedése, felvehetősége és toxicitása erősen függ a redoxviszonyoktól. Természetes körülmények között a vas- és mangán-oxi-hidroxidok meghatározzák a táp- és mikroelemek felvehetőségét (WU et. al., 1990; BENJAMIN \& LECKIE, 1981; MCKENZIE, 1989). Számtalan vizsgálat bizonyította, hogy a Mn-, Fe- és Al-oxidok adszorpciós képességében meghatározó a redox állapot (SCHULTHESS \& HUANG, 1990; PULS \& BOHN, 1988). A CrIII menynyisége és oxidációs hajlama erősen függ a talaj könnyen redukálható Mntartalmától (BARTLETT \& JAMES, 1979).

Egy rendszer redoxpotenciálja érzékeny a pH-ra. Azok az elektródpotenciálok, amelyek potenciálmeghatározó folyamatában $\mathrm{H}^{+}$-ionok is részt vesznek, függenek az oldat $\mathrm{H}^{+}$-koncentrációjától, a pH-tól, tehát azzal együtt kell mérni.

A fent felsorolt bizonytalanságok kiküszöbölése érdekében módszert dolgoztunk ki a talajminták redox pufferképességének meghatározására. Ez gyakorlatilag olyan viszonyban áll a redoxpotenciállal, mint a savanyúság értékek esetében. Ez vizsgálati módszer függő, az esetben, ha az alkalmazott oxidálószer nem pufferolja a redox-potenciált akkor kicserélhető savanyúsággal analóg, ha pufferolja akkor a hidrolitos savanyúsággal, a pH-val. Vagyis egy olyan mennyiségi jellemzője a talajnak, amely megmutatja, hogy mennyi oxidálószerrel lehet a talajt egy adott, erösen oxidált állapotba hozni. Ezzel a mérési módszerrel kiküszöbölhetők a redoxpotenciál mérésénél említett hibák és bizonytalanságok, továbbá a talaj olyan jellemzőjét mérhetjük, mely időben és a körülmények függvényében sokkal kisebb mértékben változik. Ennek az elméleti magyarázata a következő: A talajban számtalan redoxirendszer található egymás mellett. Mindegyiknek a Nerst törvény által meghatározott redukált-oxidált koncentrációaránya úgy áll be, hogy az összes ilyen redoxipár által kialakított egyensúlyi redoxpotenciált adja. Ezek közül a rendszerek közül van néhány nagyon gyorsan beálló, kinetikailag nem gátolt rendszer (amelyek igen könnyen oldódnak, illetve deszorbeálódnak a talajszemcsék felületéről), melyek a talajszuszpenzió folyadékfázisának redoxpotenciálját alapvetően meghatározzák. A redoxpotenciál meghatározásának hibáját ezek, a talajban esetleg igen kis koncentrációban jelen levő redoxpárok okozzák, melyek a környezet hatására nagyon gyorsan változhatnak, így a szuszpenzióban tulajdonképpen nem a talajra jellemző egyensúlyi potenciált mérjük, hanem a könnyen mobilizálható, ezért gyorsan változó rész potenciálját. Egy lassú, oxidálószeres titrálással meghatározott redox-potenciál görbe alapján azonban a talaj teljes redukáló képességét is jó közelítéssel becsülhetjük, miközben megfelelő módszerrel megkaphatjuk a legnagyobb változáshoz tartozó (átcsapási) redoxpotenciál értéket is, mely a talajra jellemző, függetlenül a mintavétel körülményeitől. 


\section{Anyag és módszer}

Vizsgálataink során a redoxipotenciál mérésére platina elektródot alkalmaztunk. Referencia elektródként $\mathrm{Ag} / \mathrm{AgCl}$ elektródot használtuk. Mivel a Pt elektród potenciálja a redoxpotenciál mellett a pH-tól is nagymértékben függ, ezért önmagában alkalmatlan a redoxpotenciál mérésére. Viszont az üvegelektród potenciálja csak a pH-tól függ, a redoxpotenciáltól gyakorlatilag független, így ha a két elektród jelét ismerjük, akkor az aktuális redoxpotenciálból, az összehasonlíthatóság szempontjából fontos, 0-s pH-ra átszámolt redoxpotenciál számítható.

Egy talajszuszpenzióba merülő Pt elektród redoxpotenciáljának kialakításában számtalan reverzibilisen oxidálható, illetve redukálható pár van, melyeknek eredője alakítja ki a mérőelektród potenciálját. Ezt a potenciált a Nerst egyenlettel fejezhetjük ki:

$$
\varepsilon=\varepsilon^{\circ}+\frac{R T}{z F} \ln \frac{[o x]}{[\text { red }]}
$$

ahol: $\varepsilon=$ az adott körülmények között kialakuló elektródpotenciál $(\mathrm{V}) ; \varepsilon^{\mathrm{o}}=$ a standard elektródpotenciál (V) $\left(25^{\circ} \mathrm{C} ; 0,1 \mathrm{MPa}-n\right.$ mért normálpotenciál); $\mathrm{R}=$ az egyetemes gázállandó $\left(8,31434 \mathrm{Jmol}^{-1} \mathrm{~K}^{-1}\right) ; \mathrm{T}=\mathrm{a}$ hőmérséklet $\left(\mathrm{K}^{\mathrm{o}}\right) ; \mathrm{z}=\mathrm{a}$ redoxifolyamatban résztvevő $\mathrm{e}^{-}$-ok száma; $\mathrm{F}=$ a Faraday-féle állandó (96 $\left.486 \mathrm{Cmol}^{-1}\right)$; [ox] = az oxidált alak koncentrációja; $[\mathrm{red}]=$ a redukált alak koncentrációja.

Ezt a mérőelektródot egy $\mathrm{Ag}^{+} / \mathrm{AgCl}$ referencia elektróddal összekötve, a galvánelem elektromotoros ereje (EME) alapján a talajszuszpenzióba merülö Pt elektród potenciálja kiszámítható a következő egyenlet alapján:

$$
\mathrm{EME}=\varepsilon_{\text {katód }}-\varepsilon_{\text {anód }}
$$

ahol: $\varepsilon_{\text {katód }}=\mathrm{az} \mathrm{Ag}^{+} / \mathrm{AgCl}$ referencia elektród potenciálja $\left(\varepsilon^{\mathrm{o}}=0,222 \mathrm{~V}\right) ; \varepsilon_{\text {anód }}=\mathrm{a}$ talajszuszpenzióba merülö Pt elektród potenciálja.

Mivel a rendszer EME-jét mérni nem tudjuk - ugyanis ez akkor áll fenn, ha a galvánelemben nem folyik áram -, az EME helyére az áramtermelés közben mérhető kapocsfeszültség $\left(E_{K}\right)$ értékét helyettesítjük, amelyről tudnunk kell, hogy az mindig kisebb mint az EME.

$$
\varepsilon_{\text {anód }}=\varepsilon_{\text {katód }}-\mathrm{E}_{\mathrm{K}}
$$

A következő, $\mathrm{pH}$-változással járó redoxi reakcióra alkalmazva az előbb említetteket:

$$
\mathrm{A}_{\text {red }}+\mathrm{H}_{2} \mathrm{O}=\mathrm{A}_{\mathrm{ox}}+\mathrm{H}^{+}+\mathrm{e}^{-}
$$

ahol: $\mathrm{A}_{\text {red }}$, illetve $\mathrm{A}_{\mathrm{ox}}$ egy adott redoxipár redukált, illetve oxidált formája.

Az oldatba merülö Pt elektród potenciálja

$$
\varepsilon=\varepsilon^{\circ}+\frac{R T}{z F} \ln \frac{\left.\left[A_{\text {ox }}\right] \mid H^{+}\right]}{\left[A_{\text {red }}\right]}
$$

A mérést $25^{\circ} \mathrm{C}$-on végezve, behelyettesítve az állandókat $(\mathrm{R}, \mathrm{F})$ ln-rôl áttérve lg-ra, és átrendezve az egyenletet a következő formát kapjuk: 


$$
\varepsilon=\varepsilon^{\circ}+\frac{0,059}{z} \lg \frac{\left[A_{o x}\right]}{\left[A_{\text {red }}\right]}+\frac{0,059}{z} \lg \left[H^{+}\right]
$$

amelybe behelyettesítve a $\mathrm{pH}$ definícióját $\left(\mathrm{pH}=-\lg \left[\mathrm{H}^{+}\right]\right)$, megkapjuk a számunkra informatív formát:

$$
\varepsilon=\varepsilon^{\circ}+\frac{0,059}{z} \lg \frac{\left[A_{o x}\right]}{\left[A_{\text {red }}\right]}-\frac{0,059}{z} p H
$$

vagyis, hogy pH-egységenként $59 \mathrm{mV}$-tal változik egy rendszer redoxipotenciálja. Hogy hogyan, arra az 1. ábra ad felvilágosítást, ahol a vizes oldatokban lejátszódó elektródpotenciálok láthatóak a pH függvényében.

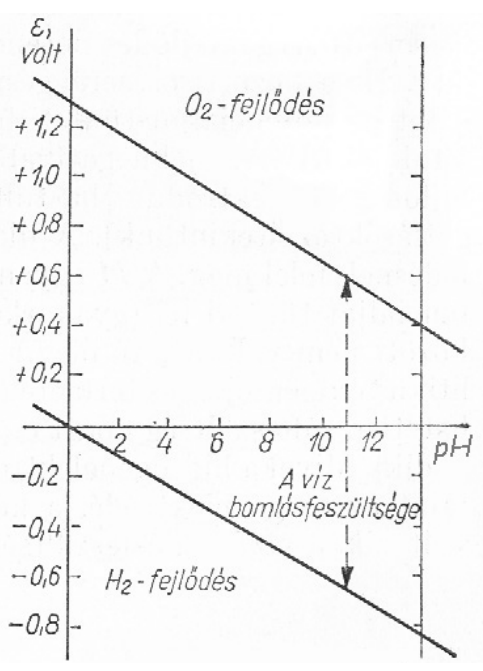

1. ábra

A hidrogén és oxigén elektródpotenciálja a $\mathrm{pH}$ függvényében (ERDEY-GRÚZ, 1972)

A hidrogén és oxigén elektródpotenciálja a $\mathrm{pH}$ függvényeként feltüntetve a két egyenes mentén változik, amelyeknek iránytangense $0,059 / z$. Ha az elektród potenciálja az alsó egyenes által jelzett értéknél negatívabb, akkor $\mathrm{H}_{2}$-fejlödés, ha a felső egyenes által jelzett értéknél pozitívabb $\mathrm{O}_{2}$-fejlődés történik.

A talajokban lejátszódó oxidációs-redukciós folyamatok a víz stabil tartományába esnek, vagyis a két egyenes által határolt tartományon belül maradnak, és a pH-val hasonló változásukat tételezzük fel. Egyes esetekben a redoxpotenciál változása a $\mathrm{pH}$-val gyors redoxváltozáskor $-200 \mathrm{mV} / \mathrm{pH}$ is lehet. A legtöbb mérésnél azonban az $59 \mathrm{mV} / \mathrm{pH}$ tényező használata célszerü, mivel a redoxpotenciálok vegyes potenciálok, a $\pm 10 \mathrm{mV}$ nál pontosabb értékek megadása nem látszik szükségesnek.

A vizsgálatoknál 100 ml-es főzőpohárban kiforralt desztillált vízhez $10 \mathrm{ml} 1$ mólos sósavoldatot adtunk, annak érdekében, hogy az oxidáláshoz szükséges savas pH-t biztosítsuk. Ehhez hozzáadtunk, még nedves, vagy fagyasztott, kb. 2 g, talajmintát, a szuszpenziót folyamatosan kevertük és az oxidálószert $\mathrm{kb} .0,1 \mathrm{~mol} / \mathrm{dm}^{3}$ $\mathrm{NaOCl}$ oldatot egyenletes időközönként változó 1-10 sec adagoltuk.

A talajmintákból ezzel a beméréssel párhuzamosan szárazanyag-tartalomra is bemértünk, majd a kiértékelésnél a nedvességtartalommal korrigáltuk a kapott értékeket.

Az RADELKIS gyártmányú üvegelektródokat két ponton 2,2 és 9,3 pH-jú RADELKIS gyártmányú pufferoldatokkal kalibráltuk. A RADELKIS gyártmányú Pt-elektród kalibrációjához az alsó értéken $1 M$ sósavoldatba szórt cinkport használtunk, vigyázva, hogy a cink ne érjen a platina felületéhez. Így gyakorlatilag egy normál hidrogén elektródot sikerült összeállítani, az így mért feszültségérték $\mathrm{mV}$ 
pontossággal megegyezett a referencia elektród elméleti potenciáljával (vagyis a Pt elektród potenciálja tényleg a normál hidrogénnek megfelelően nulla V-nak adódott). A felső kalibrációhoz a titráláshoz használt egyik oxidálószert, $0,05 \mathrm{M}$ $\mathrm{KMnO}_{4}$ oldatot, és $1 M$ sósavoldatot használtunk. A mért feszültségértékek ebben az esetben csak $\pm 5 \mathrm{mV}$-ra feleltek meg az adott koncentrációjú $\mathrm{KMnO}_{4}$ oldatra táblázatban található értékek és a referencia elektród irodalmi feszültségértékei összegének.

Az adatokat egy erősítőn és egy analóg-digitális átalakítón keresztül számítógépbe tápláltuk, ahol egy erre a célra készített célprogram tárolta a platina- és üvegelektród feszültségjelét a referencia elektródhoz képest, továbbá tárolta az időt, és adott változó 1-10 sec időközönként egy automata büretta segítségével oxidálószert adagolt a folyamatosan kevert talajszuszpenzióhoz. A mérés végén a tárolt adatokat egy szintén erre a célra készített célprogrammal értékeltük, mely első lépésben a kalibrációs értékek segítségével kiszámolta a tényleges $\mathrm{pH}$ - és redoxpotenciál értékeket. Majd az idő függvényében ábrázolta a mért adatokat. A kapott titrálási görbét állítható méretű csúszóátlag módszer segítségével a program simította, mivel az egyes mért értékek óhatatlanul hibával terheltek, mert az elektródokhoz csapódó talajszemcsék pillanatnyi potenciálingadozást okozhatnak az elektródok felületén.

A simított görbe numerikus differenciálásával kiszámította a program a derivált görbét, majd ennek a görbének a maximumát megkereste. A továbbiakban ezt tekintettük az átcsapási pontnak, vagyis ezt a potenciálértéket állítják be a talaj redox állapotát valóban meghatározó redoxpárok redukált és oxidált formáinak koncentráció arányai.

Ezen a ponton a legnagyobb a görbe meredeksége, így ezen a ponton határozható meg a legkisebb hibával az adagolt oxidálószer mennyisége a redoxpotenciál értékek függvényében.

A titrálást kezdetben 0,05 mólos $\mathrm{KMnO}_{4}$ oldattal végeztük, de mivel a keletkező mangán(II)-ionok jelentősen megváltoztatják a talaj felületét, a későbbiekben áttértünk a $\mathrm{NaOCl}$ oldatra, melynek bomlástermékei $\mathrm{Na}^{+}-\mathrm{Cl}^{-}$-ionok és víz, melyek a talaj felületét gyakorlatilag nem befolyásolják. Mivel ez egy igen bomlékony anyag, ezért a pontos koncentrációját a beméréskor nem ismerhettük - tulajdonképpen háztartási nátrium-hipoklorit oldat hígításával állítottuk elö. Emiatt minden nap, mielőtt az oldatot használni kezdtük, faktorozni kellett. A faktorozáshoz, a méréshez használt procedúrát végeztük, csak talaj helyett a pohárba ismert mennyiségü és koncentrációjú Mohr-só, $\mathrm{Fe}\left(\mathrm{NH}_{4}\right)_{2}\left(\mathrm{SO}_{4}\right)_{2}$ oldatot tettünk (melyet a humuszmeghatározáshoz is használunk a maradék $\mathrm{K}_{2} \mathrm{CrO}_{4}$ titrálására). Az erre az oldatra kapott titrálási görbe alapján számolt átcsapási pontnak megfelelö fogyásból és a bemért Mohr-só mennyiségéből számítottuk a titráló oldat pontos koncentrációját.

A titrálást elvégeztük redukciós irányban is, melyhez 0,05 mólos hidrazin oldatot használtunk, melyet 0,05 mólos $\mathrm{KMnO}_{4}$ oldattal faktoroztunk, így meghatározhattuk a redox pufferkapacitást redukciós irányban is, vagyis azt, hogy átnedvesedés esetén hogyan viselkedne a talaj.

A vizsgálatokhoz a Tisza partjáról vett talajmintákat használtunk (1. táblázat). A vizsgálati módszer kidolgozása tulajdonképpen része egy olyan vizsgálatnak, mely- 
1. táblázat

A talajminták származási helye és néhány fontos tulajdonsága

\begin{tabular}{|l|c|c|c|c|c|c|}
\hline \multicolumn{1}{|c|}{$\begin{array}{c}\text { Minta száma és } \\
\text { származási helye }\end{array}$} & $\begin{array}{c}(2) \\
\text { EOV } \\
\text { Kelet }\end{array}$ & $\begin{array}{c}(3) \\
\text { EOV } \\
\text { Észak }\end{array}$ & $\begin{array}{c}(4) \\
\mathrm{K}_{\mathrm{A}}\end{array}$ & $\begin{array}{c}\mathrm{pH} \\
(\mathrm{KCl})\end{array}$ & $\begin{array}{c}(5) \\
\mathrm{Hu}- \\
\text { musz \% }\end{array}$ & $\begin{array}{c}\mathrm{CaCO}_{3} \\
(\%)\end{array}$ \\
\hline 1. Gergelyiugornya, part & $008-94-846$ & $003-13-375$ & 48 & 6,14 & 1,34 & 0,19 \\
2. Tivadar, gáton kívül & $009-07-589$ & $003-07-880$ & 43 & 5,20 & 2,15 & - \\
3. Tivadar, hullámtér & $009-06-996$ & $003-07-639$ & 37 & 5,30 & 0,64 & - \\
4. Tivadar, part & $009-06-857$ & $003-07-587$ & 58 & 6,74 & 3,29 & 0,72 \\
5. Gergelyiugornya hullámtér & $008-94-856$ & $003-13-387$ & 53 & 6,20 & 2,43 & 0,35 \\
6. Gergelyiugornya, gáton & $008-95-750$ & $003-13-539$ & 34 & 6,87 & 0,37 & 4,95 \\
kívül & $009-02-557$ & $002-80-070$ & 55 & 6,48 & 10,28 & 0,26 \\
7. Tiborszállás - agyag & $009-02-557$ & $002-80-070$ & 49 & 6,19 & 8,90 & 0,13 \\
8. Tiborszállás - kotu & \multicolumn{1}{|c|}{} & & & & & \\
\hline
\end{tabular}

lyel a redoxviszonyok hatását igyekeztük kimutatni a nehézfémek oldhatóságára. A mintákat 2003 őszén vettük, utána hütve tároltuk.

Mivel egy egyensúlyi adat meghatározását tüztük ki célul nem egyensúlyi módszer segítségével, a vizsgálatokat különböző adagolási sebességekkel is elvégeztük. Ezek minden minta esetében a következök voltak: 0,5, 1, 2, 5,5, 10, 20 másodperc adagolásonként, vagyis 0,0025 ml-enként.

\section{2. táblázat}

Oxidációs (A), ill. redukciós (B) pufferkapacitás értékek, mmol/kg talaj az egyes mintáknál az adagolások között eltelt különböző időtartamok esetén

\begin{tabular}{|c|c|c|c|c|c|c|c|c|c|}
\hline \multirow{2}{*}{$\begin{array}{l}\text { (1) } \\
\text { Idő }\end{array}$} & \multicolumn{8}{|c|}{ (2) Minta száma } & \multirow{2}{*}{$\begin{array}{c}\text { (3) } \\
\text { Átlag }\end{array}$} \\
\hline & 1 & 2 & 3 & 4 & 5 & 6 & 7 & 8 & \\
\hline \multicolumn{10}{|c|}{ A. Oxidációs pufferkapacitás értékek } \\
\hline 0,5 & 3.46 & 1.44 & 0.96 & 5.19 & 1.66 & 1.23 & 2.60 & 2.17 & 2.34 \\
\hline 1 & 2.69 & 1.54 & 0.98 & 5.39 & 1.93 & 1.07 & 3.75 & 2.46 & 2.48 \\
\hline 2,5 & 3.26 & 2.38 & 0.88 & 5.21 & 2.46 & 1.00 & 2.36 & 2.69 & 2.53 \\
\hline 5 & 3.96 & 1.99 & 0.90 & 8.67 & 1.97 & 1.00 & 8.84 & 3.63 & 3.87 \\
\hline 10 & 4.20 & 3.36 & 0.86 & 6.17 & 3.32 & 0.70 & 7.71 & 2.75 & 3.63 \\
\hline 20 & 6.23 & 2.48 & 0.92 & 6.17 & 9.90 & 0.94 & 18.47 & 3.14 & 4.78 \\
\hline a) átlag & 3.97 & 2.20 & 0.92 & 6.13 & 3.54 & 0.99 & 5.62 & 2.81 & \\
\hline \multicolumn{10}{|c|}{ A. Redukciós pufferkapacitás értékek } \\
\hline 0,5 & 5.63 & 4.65 & 5.93 & 5.03 & 5.10 & 4.13 & 4.58 & 3.98 & 4.88 \\
\hline 1 & 2.93 & 4.73 & 4.80 & 5.10 & 3.60 & 3.45 & 3.38 & 3.83 & 3.98 \\
\hline 2,5 & 3.23 & 4.13 & 3.68 & 3.53 & 3.15 & 2.70 & 2.78 & 2.55 & 3.22 \\
\hline 5 & 6.08 & 3.00 & 3.08 & 3.15 & 2.78 & 3.08 & 3.60 & 2.78 & 3.44 \\
\hline 10 & 2.33 & 2.55 & 2.93 & 2.63 & 2.70 & 2.78 & 3.23 & 2.70 & 2.73 \\
\hline 20 & 2.78 & 2.40 & 2.78 & 2.63 & 2.48 & 2.25 & 2.40 & 2.40 & 2.51 \\
\hline a) átlag & 3.83 & 3.58 & 3.86 & 3.68 & 3.30 & 3.06 & 3.33 & 3.04 & \\
\hline
\end{tabular}




\section{Eredmények és értékelésük}

Vizsgáltuk, hogy az oxidációs, ill. redukciós pufferkapacitás értékek hogyan változnak az adagolások között eltelt idő függvényében (2. táblázat, 2. és 3 . ábra).

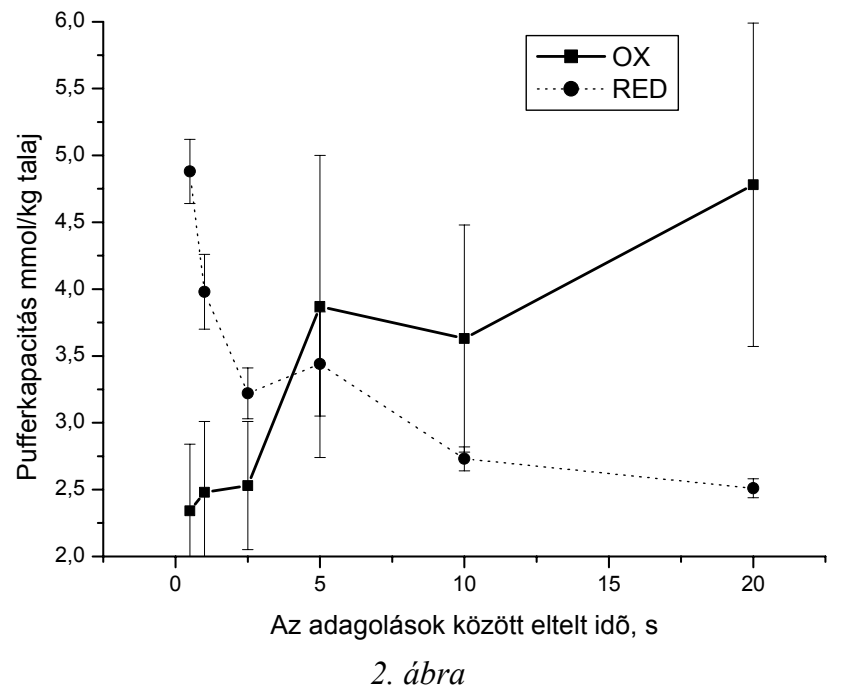

A számított oxidációs, ill. redukciós pufferkapacitás értékek (mmol/kg talaj) az adagolások között eltelt idő (másodperc) függvényében

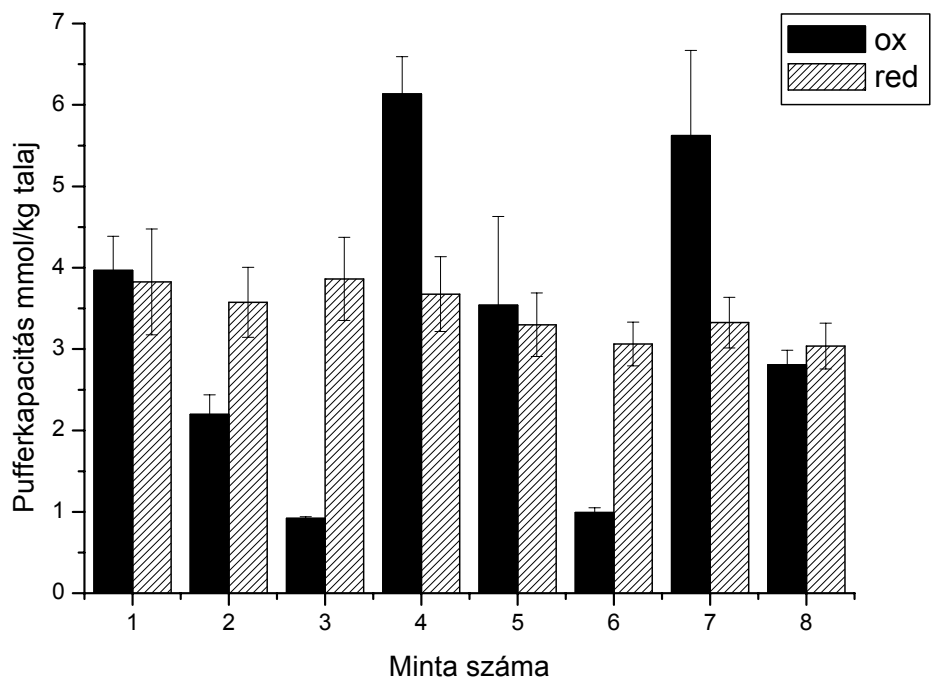

3. ábra

Az egyes mintáknál különböző időben mért pufferkapacitás értékek átlagai. Megjegyzés: a minták származási helyét lásd 1. táblázat 
A 2. ábrán látható, hogy a reduktív irányban menő folyamatok esetében a mért értékek csökkenő tendenciát, míg az oxidációs irányban haladva növekvő tendenciát mutatnak. Ez azt jelenti, hogy az egyensúlyi rendszer felé haladva (növekvő várakozási idő az adagok között) oxidációs irányban a várt eredményt kapjuk, vagyis azt, hogy a talajszemcsék felületéről egyre nagyobb mennyiségben távoznak a meghatározó anyagok. A reduktív irányban tapasztalt csökkenés magyarázatához még több vizsgálat szükséges. Érdemes megjegyezni, hogy az 5 másodperces várakozási időhöz tartozó eredmények mindkét esetben szemmel láthatóan nem követik a többi adat által sugallt tendenciát, oxidáció esetében egy lineáris növekedés, míg a redukciónál egy aszimptotához tartó csökkenés tapasztalható.

A 3. ábrán az egyes mintákra különböző időben mért értékek átlagát ábrázoltuk. Az ábrán látható, hogy míg az egyes mintákra kapott értékek az oxidációs vizsgálatnál szignifikánsan különböznek, addig a redukciós kísérletek esetében statisztikailag azonosnak tekinthetők.

\section{Összefoglalás}

A talajok redox pufferképességének mérésére kidolgoztunk egy olyan titrálásos módszert, mellyel a szakirodalomban szereplő redox vizsgálati módszerek hátrányai kiküszöbölhetök.

A mérés során nem az aktuális redoxpotenciált mérjük, hanem oxidáló vagy redukáló szeres titrálással folyamatosan változtatjuk a minta oxidációs állapotát, ezzel gyakorlatilag kiküszöböljük a mintavétel és a mintatárolás jelentős redox állapotot befolyásoló hibáit. A pH és Eh keresztkölcsönhatás kiküszöbölése érdekében párhuzamosan mérjük a rendszer pH-ját és Eh-ját és a szakirodalomból ismert korrekciókat a kiértékelő szoftver automatikusan elvégzi. A teljesen automatizált mérés során pufferkapacitás értéknek a rendszer titrálási átcsapási pontját, vagyis az inflexiós pontot vettük figyelembe, melyet a derivált görbe maximuma alapján keresett meg a program. A módszert számos magyarországi talajmintán alkalmaztuk, eltérő adagolási időkkel, és az eredményekből a redoxtulajdonságokat okozó folyamatok kinetikájára is következtethettünk.

Az oxidációs redox pufferkapacitás vizsgálatoknál azt találtuk, hogy az egyes adagolások között eltelt időt növelve a pufferkapacitás növekedett, míg a reduktív irányban csökkent. Ez a folyamatirány eltérő mechanizmusra utal.

Kulcsszavak: redoxi titrálás; redoxipotenciál; pH; pufferkapacitás

\section{Irodalom}

Amonette, J. E. et al., 1999. Redox Chemistry at Mineral Surfaces. Environmental Dynamics and Simulation (Annual Report). 
BARTLETT, R. J. \& JAMES, B. R., 1979. Behavior of chromium in soils. III. Oxidation. J. Environ. Qual. 8. 31-35.

BenJAmin, M. M. \& LeCKIE, J. O., 1981. Multiple-site adsorption of Cd, Cu, Zn, and $\mathrm{Pb}$ on amorphous iron oxyhydroxide, J. Colloid Interface Sci. 79. 209-221.

Hutcheon, I., Shevalier, M. \& ABercrombie, H. J., 1993. pH buffering by metastable mineral-fluidequilibria and evolution of carbon dioxide fugacity during burial diagenesis. Geochim. Cosmoschim. Acta. 57. 1017-1027.

MCKenZIE, R. M., 1989. Manganese oxides and hydroxides. In: Minerals in Soil Vnvironments. (Eds.: DiXON, J. B. \& WEED, S. B.) $2^{\text {nd }}$ ed. SSSA Book Series 1. 439-465. SSSA. Madison, WI.

Puls, W. R. \& BoHn, H. L., 1988. Sorption of cadmium, nickel, and zinc by kaolinite and montmorillonite suspensions. Soil Sci. Soc. Am. J. 52. 1289-1292.

Schulthess, C. P. \& HuANG, C. P., 1990. Adsorption of heavy metals by silicon and aluminum oxide surfaces on clay minerals. Soil Sci. Soc. Am. J. 54. 679-688.

VAN BREEMEN, N. \& WIELEMAKER, W. G., 1974. Buffer intensities and equilibrium pH of minerals and soils. II. Theoretical and actual $\mathrm{pH}$ of minerals and soils. Soil Sci. Soc. Amer. Proc. 38. 61-66.

Vepraskas, M. J., 2002 Redox Potential Measurements. NC State University. December.

Wu, M. L., Hseung, Y. \& Chen, J. F., 1990. (Eds.) Properties of Soil Colloids. Science Press. Beijing.

Érkezett: 2006. október 26. 


\title{
Titration method for the determination of the redox buffering capacity of soils
}

\author{
I. ISSA, G. RÉTHÁTI, P. CZANIK and I. CZINKOTA
}

Department of Soil Science and Agricultural Chemistry, Szent István University, Gödöllő

\section{Summary}

A titration method has been elaborated for the measurement of the redox buffering capacity of the soil, which offsets most of the disadvantages of conventional measuring, because more than just the actual redox potential is detected. During the measurement, the redox state of the samples is changed continuously by titration with reducing or oxidising agents, thus practically eliminating sampling and sample storage errors that influence the redox state. To avoid problems associated with the $\mathrm{pH}$-Eh cross effect, both values are measured in parallel, and corrections are automatically made by the evaluation software. During the automated measurements, the inflexion point of the redox potential curve was taken as the buffering capacity value, calculated as the maximal value of the derivative curve. This method was used for a large number of Hungarian soil samples, with different addition times, and was also suitable for investigating the kinetic properties of soil redox processes. In the case of oxidative redox buffering capacity measurements, it was found that the buffering capacity increased with an increase in the time between additions, while it decreased for reductive measurements. This suggests the existence of different mechanisms for the two processes.

This method was elaborated for determining of the redox buffer ability of soil samples. Its relationship to the redox potential is similar to that of the acidity values to $\mathrm{pH}$. The acidity value depends on the analytical methods. If the applied oxidant does not buffer the redox potential, it can be substituted by acidity, otherwise by hydrolytic acidity. Therefore, it is an extensive quantitative feature of soil, which shows the quantity of oxidants that makes it possible to bring the soil into a given, strongly oxidated state. By use of this method, the errors mentioned in the case of redox potential measurement can be eliminated, and moreover, a characteristic feature of soil, that changes to a far lesser extent as a function of time and conditions, can be measured.

Table 1. Origin and major properties of the soil samples. (1) Number and origin of sample. 1. Gergelyugornya, river bank. 2. Tivadar, beyond the embankment. 3. Tivadar, flood-plain. 4. Tivadar, river bank. 5. Gergelyugornya, flood-plain. 6. Gergelyugornya, beyond the embankment. 7. Tiborszállás, clay. 8. Tiborszállás, "kotu" (peat) (2) EOV East. (3) EOV North. (4) Upper limit of plasticity according to Arany. (5) Humus, \%.

Table 2. Oxidative (A) and reductive (B) buffering capacity values (mmol/ $\mathrm{kg}$ soil) for the individual samples, for different times between additions. (1) Time. a) Mean. (2) Sample No. (3) Mean.

Fig. 1. Hydrogen and oxygen electrode potential as a function of $\mathrm{pH}$. From top to bottom: $\mathrm{O}_{2}$ production; decomposition voltage of water; $\mathrm{H}_{2}$ production.

Fig. 2. Calculated oxidative and reductive buffering capacity values ( $\mathrm{mmol} / \mathrm{kg}$ soil) as a function of the time between additions (s).

Fig. 3. Mean value of buffering capacity measured at different times for individual samples. Note: for origin of samples, see Table 1. 